\title{
Cross-year Peer Tutoring in Healthcare and Dental Education: A Review of the Literature
}

\author{
Lauren Hum $^{1}$, Justin Maccaro ${ }^{2}$ \& Sang E. Park ${ }^{3, *}$ \\ ${ }^{1}$ Harvard School of Dental Medicine, Boston, USA \\ ${ }^{2}$ University of the Pacific, Arthur A. Dugoni School of Dentistry, San Francisco, USA \\ ${ }^{3}$ Office of Dental Education, Harvard School of Dental Medicine, Boston, USA \\ *Corresponding author: Office of Dental Education, Harvard School of Dental Medicine, 188 Longwood Ave., \\ Boston, MA 02115, USA. E-mail: sang_park@hsdm.harvard.edu
}

Received: May 23, 2014

Accepted: June 20, $2014 \quad$ Online Published: July 28, 2014

doi:10.5430/jct.v3n2p43

URL: http://dx.doi.org/10.5430/jct.v3n2p43

\begin{abstract}
Cross-year peer tutoring (CYPT) programs show promise of potential benefits not only to the tutees and tutors, but also to the entire dental education field. A critical review of the literature was performed to determine the characteristics of studies assessing CYPT programs in the healthcare field, to see if there are adequate resources in the literature to aid dental institutions in making evidence-based decisions about their curriculum.

A PubMed literature search was conducted to identify pertinent research. Only those articles that demonstrated programs that paired junior and senior students were included. A total of twenty articles were identified and analyzed for the characteristics of the CYPT program, the study groups compared, and the outcomes assessed. In the few studies that examined qualitative outcomes, many found success measured in positive outcomes for the tutors. However, there are too few studies that examine the qualitative outcomes of tutor interest in careers in dental education.

With more contributions to literature in the dental field that specifically target preclinical dental education and tutor interest in careers in education, published within the context of the curriculum, dental education institutions can begin making more evidence-based decisions on the incorporation of CYPT programs into their curricula.
\end{abstract}

Keywords: peer teaching; tutoring; health care education; dental education

\section{Introduction}

Topping (1996) defined peer tutoring as "people from similar social groupings who are not professional teachers but help each other to learn and learn themselves from teaching." With this expected combination of outcomes, healthcare institutions are examining their cross-year peer tutoring (CYPT) programs in order to determine program effectiveness in maintaining the academic performance of their students, while enhancing the education of the tutees and tutors. A 2011 study found that in the 36 dental schools responding to the survey, 25 of the programs implement some formal teaching program involving teaching assistants, fellowships, or peer tutoring. (McAndrew, Brunson, \& Kamboj, 2011) The 2009 senior survey conducted by the American Dental Education Association found that 44.3\% of graduates plan to teach at some point in their career. However, graduating dental classes produce less than $1 \%$ of new dentists with immediate plans to enter teaching. (Okwuje, Anderson, \& Valachovic, 2010). Additionally, a 2007-2008 association report indicated 369 full- and part-time vacant faculty positions. (Okwuje, Sisson, Anderson, \& Valachovic, 2009). Therefore, CYPT programs benefit tutors by preparing them to teach at some point in their careers. In addition, CYPT programs have the potential to initiate interest in pursuit of full-time academic careers-a component that the dental field is in high need of.

Studies on CYPT programs have mostly involved junior students within their first two years at the institution, being tutored by senior students on physical exam and clinical skills topics, in addition to general academic assistance programs. Generally, there is substantial evidence that peer tutoring has many positive effects for the tutees: improved test scores, student satisfaction, personal and professional development. (Topping, 1996). Several studies 
have also found that tutors benefit by improving their own understanding of the course content, developing communications skills, and gaining confidence. All of these benefits enhance the tutors' professional development early on in their careers.

With greater financial demands and a need to generate new dentists with plans to enter academic careers, CYPT programs are vital to dental education institutions and the field as a whole. Thus, our study did a critical review of the literature involving cross-year peer tutoring programs that involved the pairing of junior and senior students. The characteristics of the CYPT programs in each study reviewed were examined to determine factors for success. Additionally, this research elucidated characteristics necessary for future studies on CYPT programs if these studies are to aid dental education institutions in deciding whether to incorporate CYPT programs in their curricula.

\section{Methods}

\subsection{Inclusion and Exclusion Criteria}

Only studies published in English examining the impact of peer tutoring between professional healthcare students were included. Additionally, only studies that demonstrated programs that paired upperclassman tutors with underclassmen tutees were included. Included studies identified cross-year peer tutoring as an interpersonal educational relationship between two students: the tutor is the more experienced student who has been through at least one year of school, while the tutee is at least one year his junior and receives some method of educational assistance from the tutor. In order to examine a large number and variety of studies, no limitations were made on sample size, study format, or publication date.

\subsection{Literature Search}

A PubMed literature search was conducted to identify papers that studied the effects of cross-year peer tutoring on healthcare curricula. Several search methods were used to identify articles. MeSH Terms "Education, Medical”, and "Education, Dental" were used to properly isolate relevant studies. These initial article lists were then narrowed with search phrases such as, "peer tutoring”, "peer mentoring”, and "peer assisted learning”. Bibliographies of identified articles were reviewed for additional pertinent studies.

Articles were then selected based on certain criteria. Each article was examined and categorized based on subject matter and participants, goal of the study, groups of students evaluated, how the program was evaluated, the overall result of the study, and study limitations. The specific characteristics of each tutor program were also evaluated, including tutor selection criteria, tutor training, faculty involvement, tutor-tutee ratio, program time, tutor compensation, and whether tutors took over some of faculty members' teaching responsibility.

As study format varied drastically within the articles compiled, it was not possible to do any large meta-analysis of data collected. Instead, this review aimed to achieve a broad characterization of the different types of existing cross-year peer tutoring programs in place, and to qualitatively examine the overall influence of these programs on healthcare education.

\section{Results}

A total of twenty articles were identified that paired junior and senior students together in interpersonal educational relationships. All twenty studies were analyzed for the characteristics of the peer tutoring program, the study groups that were compared, and the outcomes that were assessed.

The purpose of this review is two-fold. Firstly, to determine the context in which CYPT programs have found success; additionally, to elucidate the types of future studies needed to aid dental schools in making evidence-based decisions about utilizing CYPT programs. Therefore, our research examines the characteristics of CYPT programs (Table 1), the study groups of each CYPT program (Table 2), and the outcomes of the CYPT programs (Table 3) in the literature reviewed. A summary of each individual article, including the limitations on each, can be found in Table 4. 
Table 1. Characteristics of CYPT Programs in the Literature Reviewed

\begin{tabular}{|c|c|}
\hline \multicolumn{2}{|l|}{ Type of program? } \\
\hline Medical & 15 \\
\hline Dental & 4 \\
\hline Physical Therapy & 1 \\
\hline \multicolumn{2}{|l|}{ Content tutored } \\
\hline Didactic course/Basic Sciences & 6 \\
\hline Physical exam/History taking/Clinical Skills & 14 \\
\hline \multicolumn{2}{|l|}{ All Tutors participated voluntarily? } \\
\hline Yes & 17 \\
\hline Not mentioned & 3 \\
\hline \multicolumn{2}{|l|}{ Tutors selected based on set criteria? } \\
\hline Yes & 11 \\
\hline No & 7 \\
\hline Not Specified & 2 \\
\hline \multicolumn{2}{|l|}{ Number of hours tutors were trained } \\
\hline 0 & 7 \\
\hline $1-5$ & 3 \\
\hline$>5$ & 3 \\
\hline Not specified & 7 \\
\hline \multicolumn{2}{|c|}{$\begin{array}{l}\text { Faculty members involved in tutoring program beyond } \\
\text { training of tutors? }\end{array}$} \\
\hline Yes & 6 \\
\hline No & 14 \\
\hline \multicolumn{2}{|l|}{ Tutee participation voluntary? } \\
\hline Yes & 7 \\
\hline No & 12 \\
\hline Not mentioned & 1 \\
\hline \multicolumn{2}{|l|}{ Number of subjects involved in each study } \\
\hline$<50$ & 5 \\
\hline $50-100$ & 9 \\
\hline$>100$ & 5 \\
\hline Not specified & 1 \\
\hline \multicolumn{2}{|l|}{ Number of tutees working with one tutor } \\
\hline 1 & 2 \\
\hline $2-5$ & 4 \\
\hline$>5$ & 8 \\
\hline Not specified & 6 \\
\hline \multicolumn{2}{|l|}{ Total amount of time tutor spent with tutee } \\
\hline$<10$ hours & 5 \\
\hline$>10$ hours & 9 \\
\hline Not specified & 6 \\
\hline \multicolumn{2}{|l|}{ Length of tutoring program } \\
\hline Single session & 3 \\
\hline Multiple sessions & 8 \\
\hline Entire course or semester & 6 \\
\hline Multiple semesters or years & 3 \\
\hline \multicolumn{2}{|l|}{ Tutors paid for time? } \\
\hline Yes & 12 \\
\hline No or not specified & 8 \\
\hline \multicolumn{2}{|c|}{$\begin{array}{l}\text { Tutors took over some of faculty members' teaching } \\
\text { responsibility? }\end{array}$} \\
\hline Yes & 13 \\
\hline No & 7 \\
\hline
\end{tabular}




\begin{tabular}{lr}
\hline Tutees were only those who were not performing well \\
academically? \\
Yes \\
No & 19 \\
\hline
\end{tabular}

Table 2. Study Groups Evaluated in the Literature Reviewed

Comparing outcomes: Peer tutor vs. no tutor 3

Comparing outcomes: Peer tutor vs. faculty 9

Comparing outcomes: Peer tutor vs. no peer tutor vs. faculty

Comparing outcomes: views of tutees in faculty and peer tutors combined teaching situations

2

Qualitative outcomes: views of tutees on tutoring program

Qualitative outcomes: views of peer tutors on tutoring

Table 3. Outcomes of CYPT Programs in the Literature Reviewed

\begin{tabular}{ll}
\hline Quantitative assessments: evaluation scores & 8 \\
\hline Written test & 5 \\
• No significant difference in scores & 1 \\
- $\quad$ Tuculty > Tutors $>$ Faculty & 0 \\
- Tutors > No tutors & 2 \\
Rating by assessor & 11 \\
$\bullet \quad$ No significant difference in scores & 9 \\
- Faculty > Tutors $\quad$ Tutors > Faculty & 0 \\
Qualitative ratings: peer tutor/tutee experience & 3 \\
Peer tutors liked/favored experience & \\
Peer tutors likely to pursue teaching due to experience & 4 \\
Peer tutors have no significant increase in likelihood to pursue teaching due to experience & 1 \\
Tutees comparison rating & 1 \\
$\bullet \quad$ No significant difference in rating & 8 \\
- Faculty > peer tutors $\quad$ Peer tutors > faculty & 3 \\
In peer tutor vs. no peer tutor, rated tutoring as helpful & 1 \\
Qualitative assessment of current tutoring programs- tutees are positive about it & 4 \\
Peer tutors were more reliable than faculty for duties & 1 \\
\hline
\end{tabular}


Table 4. Published Studies of Peer Tutoring Programs in Health Professional Schools

\begin{tabular}{|c|c|c|c|c|c|c|}
\hline $\begin{array}{l}\text { Author Year } \\
\text { Country }\end{array}$ & $\begin{array}{l}\text { Subject Matter } \\
\text { and Participants }\end{array}$ & $\begin{array}{l}\text { Factors Examined } \\
\text { by Study }\end{array}$ & $\begin{array}{l}\text { Groups } \\
\text { evaluated (n) }\end{array}$ & $\begin{array}{l}\text { Evaluation } \\
\text { Methods }\end{array}$ & Results & Limitations \\
\hline Haist 1998 USA & $\begin{array}{l}\text { Subject: physical } \\
\text { examination } \\
\text { Tutors: 4th year } \\
\text { medical students } \\
\text { (M4) } \\
\text { Tutees: 1st year } \\
\text { medical students } \\
\text { (M1) }\end{array}$ & $\begin{array}{l}\text { Student performance } \\
\text { on written and } \\
\text { practical examination } \\
\text { when tutored by peers } \\
\text { or faculty. } \\
\text { Student ratings of } \\
\text { faculty vs peer } \\
\text { preceptors. } \\
\text { Impact of program on } \\
\text { peer tutors. }\end{array}$ & $\begin{array}{l}\text { Students tutored } \\
\text { by peers or staff } \\
\text { (93 students } \\
\text { overall) }\end{array}$ & $\begin{array}{l}\text { Mean scores } \\
\text { (adjusted based on } \\
\text { GPA) on a written } \\
\text { test and an } \\
\text { observed hour-long } \\
\text { standard patient } \\
\text { examination. } \\
\text { Students rated } \\
\text { preceptors at end of } \\
\text { course. } \\
\text { Student preceptors } \\
\text { rated experience. }\end{array}$ & $\begin{array}{l}\text { Written test scores not } \\
\text { significantly different. } \\
\text { Standardized patient exam } \\
\text { scores not significantly } \\
\text { different. } \\
\text { M1 rated peer preceptors } \\
\text { higher in all specific items. } \\
\text { M4 preceptors rated their } \\
\text { experiences very favorably. }\end{array}$ & $\begin{array}{l}\text { Done at single } \\
\text { institution } \\
\text { Very basic skills taught } \\
\text { Student preceptors } \\
\text { selected based on } \\
\text { academic success }\end{array}$ \\
\hline Haist 1997 USA & $\begin{array}{l}\text { Subject: physical } \\
\text { examination } \\
\text { Tutors: M4 } \\
\text { Tutees: M1 }\end{array}$ & $\begin{array}{l}\text { Student performance } \\
\text { on written and } \\
\text { practical examination } \\
\text { when tutored by peers } \\
\text { or faculty. } \\
\text { Student ratings of } \\
\text { faculty vs peer } \\
\text { preceptors. } \\
\text { Impact of program on } \\
\text { peer tutors. }\end{array}$ & $\begin{array}{l}\text { Students tutored } \\
\text { by peers (36) } \\
\text { Students tutored } \\
\text { by faculty (64) }\end{array}$ & $\begin{array}{l}\text { Mean scores on a } \\
\text { written exam and a } \\
\text { practical } \\
\text { examination } \\
\text { (evaluated by } \\
\text { standardized } \\
\text { patients). } \\
\text { Students rated } \\
\text { preceptors at end of } \\
\text { course. } \\
\text { Student preceptors } \\
\text { rated experience. }\end{array}$ & $\begin{array}{l}\text { Scores on a written and } \\
\text { practical examination were } \\
\text { not significantly different. } \\
\text { No significant differences in } \\
\text { how students rated peer } \\
\text { preceptors vs faculty } \\
\text { preceptors. } \\
\text { M4 preceptors rated their } \\
\text { experiences very favorably. }\end{array}$ & $\begin{array}{l}\text { Done at single } \\
\text { institution } \\
\text { Very basic skills taught } \\
\text { Student preceptors } \\
\text { selected based on } \\
\text { academic success }\end{array}$ \\
\hline Barnes 1978 USA & $\begin{array}{l}\text { Subject: medical } \\
\text { history, physical } \\
\text { examination } \\
\text { Tutors: M4 } \\
\text { Tutees: M2 }\end{array}$ & $\begin{array}{l}\text { Student performance } \\
\text { on practical } \\
\text { examination when } \\
\text { tutored by peers or } \\
\text { faculty. } \\
\text { Student ratings of } \\
\text { faculty vs peer } \\
\text { preceptors. } \\
\text { Peer tutor perceived } \\
\text { ability and impact of } \\
\text { program. }\end{array}$ & $\begin{array}{l}\text { Students tutored } \\
\text { by peers (13) } \\
\text { Students tutored } \\
\text { by faculty (14) }\end{array}$ & $\begin{array}{l}\text { Independent, } \\
\text { blinded trained } \\
\text { reviewer judged } \\
\text { performance on } \\
\text { history and } \\
\text { physical exam. } \\
\text { Students rated } \\
\text { preceptors at } \\
\text { beginning and end } \\
\text { of course. } \\
\text { Student tutors rated } \\
\text { experience. }\end{array}$ & $\begin{array}{l}\text { No significant differences in } \\
\text { the performances. } \\
\text { At both beginning and end } \\
\text { evaluations students rated } \\
\text { student tutors better at giving } \\
\text { helpful suggestions. } \\
\text { M4 preceptors rated their } \\
\text { experiences very favorably } \\
\text { and were confident in their } \\
\text { ability to serve as effective } \\
\text { tutors. }\end{array}$ & $\begin{array}{l}\text { Done at single } \\
\text { institution } \\
\text { Relatively small sample } \\
\text { size } \\
\text { Results may not be } \\
\text { generalizable to other } \\
\text { types of peer tutoring }\end{array}$ \\
\hline $\begin{array}{l}\text { Trevino and } \\
\text { Eiland, } 1980 \text { USA }\end{array}$ & $\begin{array}{l}\text { Subject: various } \\
\text { basic science } \\
\text { courses } \\
\text { Tutors: graduate } \\
\text { students, advanced } \\
\text { medical students } \\
\text { Tutees: M1, M2 }\end{array}$ & $\begin{array}{l}\text { If peer tutorial } \\
\text { program improves } \\
\text { test scores of } \\
\text { poor-performing } \\
\text { students. }\end{array}$ & $\begin{array}{l}\text { Same students } \\
\text { before and after } \\
\text { tutoring was } \\
\text { introduced (55) }\end{array}$ & $\begin{array}{l}\text { Average course } \\
\text { grade (method of } \\
\text { assessment not } \\
\text { mentioned) }\end{array}$ & $\begin{array}{l}\text { Average course grades } \\
\text { higher after tutoring. }\end{array}$ & $\begin{array}{l}\text { Only students } \\
\text { performing poorly } \\
\text { tutored } \\
\text { No comparison group } \\
\text { Peer tutors highly } \\
\text { selected and paid }\end{array}$ \\
\hline Lake, 1999, USA & $\begin{array}{l}\text { Subject: physiology } \\
\text { Tutors: 5th year } \\
\text { physical therapy } \\
\text { students (PT5) } \\
\text { Tutees: PT3 }\end{array}$ & $\begin{array}{l}\text { If peer tutoring } \\
\text { program helps } \\
\text { improve performance } \\
\text { as students move } \\
\text { from introductory to } \\
\text { advanced course. } \\
\text { Junior students views } \\
\text { on peer tutoring }\end{array}$ & $\begin{array}{l}\text { Students enrolled } \\
\text { in the course } \\
\text { when peer } \\
\text { tutoring was } \\
\text { available (69) } \\
\text { Students enrolled } \\
\text { in the course } \\
\text { when peer } \\
\text { tutoring wasn't } \\
\text { available (45) }\end{array}$ & $\begin{array}{l}\text { Difference between } \\
\text { the introductory } \\
\text { course grade and } \\
\text { the advanced } \\
\text { course grade; Letter } \\
\text { grades converted } \\
\text { into points on an } 11 \\
\text { point system. } \\
\text { Students' } \\
\text { perceptions } \\
\text { measured by two } \\
\text { questions as part of } \\
\text { the end-of-term } \\
\text { student course } \\
\text { evaluation. }\end{array}$ & $\begin{array}{l}\text { Those enrolled when peer } \\
\text { tutoring was available had a } \\
\text { smaller decline in course } \\
\text { grade. } \\
\text { Those who attended the } \\
\text { tutoring sessions rated their } \\
\text { perceived value of the } \\
\text { tutoring sessions highly and } \\
\text { expressed strong interest in } \\
\text { having tutoring sessions for } \\
\text { future courses. }\end{array}$ & $\begin{array}{l}\text { Compares two different } \\
\text { semesters of students } \\
\text { Does not factor in if } \\
\text { exams were identical }\end{array}$ \\
\hline $\begin{array}{l}\text { Matthes, 2002, } \\
\text { Germany }\end{array}$ & $\begin{array}{l}\text { Subject: problem- } \\
\text { based learning } \\
(\mathrm{PBL}) \text { in }\end{array}$ & $\begin{array}{l}\text { Whether peer vs } \\
\text { faculty tutoring in } \\
\text { problem based }\end{array}$ & $\begin{array}{l}\text { Students tutored } \\
\text { by peers, junior } \\
\text { faculty or senior }\end{array}$ & $\begin{array}{l}\text { Mean exam scores } \\
\text { (multiple choice } \\
\text { questions, short- }\end{array}$ & $\begin{array}{l}\text { Mean exam scores not } \\
\text { significantly different. }\end{array}$ & $\begin{array}{l}\text { Traditional exam may } \\
\text { not be reflective } \\
\text { evaluation of }\end{array}$ \\
\hline
\end{tabular}




\begin{tabular}{|c|c|c|c|c|c|c|}
\hline & $\begin{array}{l}\text { pharmacology } \\
\text { Tutors: M4 or more } \\
\text { advanced medical } \\
\text { students } \\
\text { Tutees: M3 }\end{array}$ & $\begin{array}{l}\text { learning affects the } \\
\text { results of process } \\
\text { evaluation by } \\
\text { participants or their } \\
\text { learning outcome }\end{array}$ & $\begin{array}{l}\text { faculty (787 } \\
\text { students overall) }\end{array}$ & essay) & & $\begin{array}{l}\text { effectiveness of PBL } \\
\text { Student tutors may make } \\
\text { shortcuts that direct } \\
\text { learning activity toward } \\
\text { exam-related objectives }\end{array}$ \\
\hline $\begin{array}{l}\text { Nestel and Kidd, } \\
\text { 2003, United } \\
\text { Kingdom }\end{array}$ & $\begin{array}{l}\text { Subject: } \\
\text { interviewing } \\
\text { patients } \\
\text { Tutors: M3 } \\
\text { Tutees: M1 }\end{array}$ & $\begin{array}{l}\text { Impact on first-year } \\
\text { medical students of } \\
\text { peer tutoring in } \\
\text { patient-centered } \\
\text { interviewing. }\end{array}$ & $\begin{array}{l}\text { Students tutored } \\
\text { by peers (20) } \\
\text { Students tutored } \\
\text { by faculty (19) }\end{array}$ & $\begin{array}{l}\text { Mean rating of } \\
\text { interviewing skills } \\
\text { by independent } \\
\text { assessors and } \\
\text { simulated patient's } \\
\text { rating of student's } \\
\text { interviewing skills } \\
\text { and satisfaction } \\
\text { with the interview. } \\
\text { First-year students' } \\
\text { experiences of the } \\
\text { simulated patient } \\
\text { sessions were } \\
\text { evaluated } \\
\text { immediately } \\
\text { following session. }\end{array}$ & $\begin{array}{l}\text { No differences seen in the } \\
\text { ratings given by the } \\
\text { independent assessors or } \\
\text { simulated patients. } \\
\text { Significant difference for } \\
\text { patient satisfaction. } \\
\text { More students in groups } \\
\text { facilitated by medical } \\
\text { teachers reported completely } \\
\text { meeting learning objectives } \\
\text { and practiced completely } \\
\text { effective teaching } \\
\text { techniques. }\end{array}$ & $\begin{array}{l}\text { Peer tutors contributed } \\
\text { to just one of six } \\
\text { sessions } \\
\text { Period between the } \\
\text { session and the } \\
\text { interviewing assessment } \\
\text { Single cohort of students }\end{array}$ \\
\hline $\begin{array}{l}\text { Rund, 1977, } \\
\text { USA }\end{array}$ & $\begin{array}{l}\text { Subject: physical } \\
\text { diagnosis } \\
\text { Tutors: final year } \\
\text { medical students } \\
\text { Tutees: M1 taught } \\
\text { by students; M2 } \\
\text { taught by faculty }\end{array}$ & $\begin{array}{l}\text { If a student-taught } \\
\text { course in physical } \\
\text { diagnosis was as } \\
\text { effective as a } \\
\text { traditional } \\
\text { faculty-taught course }\end{array}$ & $\begin{array}{l}\text { M1 who } \\
\text { volunteered to be } \\
\text { taught by peers } \\
\text { (17) } \\
\text { M2 taught by } \\
\text { faculty the year } \\
\text { prior who } \\
\text { volunteered to } \\
\text { take the exam } \\
\text { (17) }\end{array}$ & $\begin{array}{l}\text { Multiple choice and } \\
\text { fill in the blank } \\
\text { exam; ratings of } \\
\text { interviewing skills } \\
\text { and 'human } \\
\text { warmth' by a } \\
\text { person acting as a } \\
\text { patient }\end{array}$ & $\begin{array}{l}\text { Performance was similar on } \\
\text { all assessment methods, } \\
\text { except M2 students } \\
\text { performed better on a portion } \\
\text { of the multiple choice test } \\
\text { covering vocabulary. }\end{array}$ & $\begin{array}{l}\text { Students were chosen } \\
\text { randomly from } \\
\text { volunteers and not from } \\
\text { entire class } \\
\text { Students knew they } \\
\text { were an experimental } \\
\text { group }\end{array}$ \\
\hline $\begin{array}{l}\text { Schaffer 1990, } \\
\text { USA }\end{array}$ & $\begin{array}{l}\text { Subject: General } \\
\text { academic } \\
\text { assistance } \\
\text { Tutors: M2 and M4 } \\
\text { and graduate } \\
\text { students } \\
\text { Tutees: M1 and } \\
\text { M2, respectively }\end{array}$ & $\begin{array}{l}\text { Participation levels in } \\
\text { the tutorial program } \\
\text { via a retrospective } \\
\text { study compared to } \\
\text { available performance } \\
\text { parameters to see if } \\
\text { students seeking } \\
\text { tutoring were those } \\
\text { receiving poor grades } \\
\text { on examinations }\end{array}$ & $\begin{array}{l}\text { M1 tutored (228) } \\
\text { M1 not tutored } \\
\text { (198) } \\
\text { M2 tutored (88) } \\
\text { M2 not tutored } \\
\text { (316) }\end{array}$ & $\begin{array}{l}\text { Correlation was } \\
\text { made between } \\
\text { students who } \\
\text { sought tutoring and } \\
\text { who had been } \\
\text { identified by } \\
\text { academic } \\
\text { committee as } \\
\text { performing below } \\
\text { satisfactory on } \\
\text { examinations }\end{array}$ & $\begin{array}{l}\text { A statistically significant } \\
\text { relationship was found to } \\
\text { exist between poor } \\
\text { performance on } \\
\text { examinations and } \\
\text { participation in the tutorial } \\
\text { program for both the first } \\
\text { and second-year medical } \\
\text { students. }\end{array}$ & $\begin{array}{l}\text { Other factors involved } \\
\text { in seeking tutoring } \\
\text { besides academic } \\
\text { performance } \\
\text { Retrospective and not } \\
\text { controlled }\end{array}$ \\
\hline $\begin{array}{l}\text { Ebbert, 1999, } \\
\text { USA }\end{array}$ & $\begin{array}{l}\text { Subject: General } \\
\text { academic } \\
\text { assistance } \\
\text { Tutors: M2 } \\
\text { Tutees: M1 and 1st } \\
\text { year dental students } \\
\text { (D1) }\end{array}$ & $\begin{array}{l}\text { Tutee and tutor } \\
\text { opinion of programs } \\
\text { and their affect on } \\
\text { academic } \\
\text { performance }\end{array}$ & $\begin{array}{l}\text { Students utilizing } \\
\text { peer tutoring } \\
\text { program } \\
\text { No control group }\end{array}$ & $\begin{array}{l}\text { Written surveys of } \\
\text { year-one dental and } \\
\text { year-two co-op } \\
\text { volunteers }\end{array}$ & $\begin{array}{l}\text { Student responses were } \\
\text { generally positive especially } \\
\text { to new teaching formats. } \\
\text { M1 and D1 report program } \\
\text { good for basic science } \\
\text { concepts, tips for studying } \\
\text { and test taking, and } \\
\text { "surviving” first years of } \\
\text { school. M2 reported better } \\
\text { teaching skills, more } \\
\text { collegial interactions, and } \\
\text { reviewing for USMLE step } 1 \\
\text { material }\end{array}$ & $\begin{array}{l}\text { Qualitative study with } \\
\text { no quantitative evidence } \\
\text { of efficacy } \\
\text { No report on number of } \\
\text { students or number of } \\
\text { tutors, tutoring hours } \\
\text { No details on survey } \\
\text { questions or } \\
\text { quantitative survey scale } \\
\text { results }\end{array}$ \\
\hline $\begin{array}{l}\text { Goodfellow \& } \\
\text { Schofield, 2001, } \\
\text { United Kingdom }\end{array}$ & $\begin{array}{l}\text { Subject: respiratory } \\
\text { examination } \\
\text { Tutors: M4 } \\
\text { Tutees: M3 }\end{array}$ & $\begin{array}{l}\text { Success of peer } \\
\text { tutorials }\end{array}$ & $\begin{array}{l}\text { Students utilizing } \\
\text { peer tutoring } \\
\text { program (49) }\end{array}$ & $\begin{array}{l}\text { Evaluation } \\
\text { questionnaire } \\
\text { completed by } \\
\text { students who } \\
\text { attended peer } \\
\text { tutorials using a } 10 \\
\text { centimeter visual } \\
\text { analogue scale to } \\
\text { assess responses. }\end{array}$ & $\begin{array}{l}\text { Students found the tutorials } \\
\text { useful. Students were found } \\
\text { to feel significantly more } \\
\text { capable performing a } \\
\text { respiratory examination after } \\
\text { the tutorial. }\end{array}$ & $\begin{array}{l}\text { Only one session given } \\
\text { No comparison group to } \\
\text { those who did not } \\
\text { receive tutoring } \\
\text { Small cohort }\end{array}$ \\
\hline Lopez, 2010, USA & $\begin{array}{l}\text { Subject: General } \\
\text { academic }\end{array}$ & $\begin{array}{l}\text { Peer mentoring } \\
\text { program effectiveness }\end{array}$ & $\begin{array}{l}\text { Students who } \\
\text { participate in }\end{array}$ & $\begin{array}{l}\text { Evaluation by } \\
\text { survey. Questions }\end{array}$ & $\begin{array}{l}70 \% \text { of respondents from all } \\
\text { classes agreed that having a }\end{array}$ & $\begin{array}{l}\text { No quantitative } \\
\text { evaluation of academic }\end{array}$ \\
\hline
\end{tabular}


assistance

Tutors: D2

and relevance to current students
Tutees: D1 mentoring

program (256) regarding benefits

of peer mentoring

program,

qualifications for mentors and preparation for mentorship, and time commitment mentor during their first year performance

helped them transition to

dental school, and 58\%

agreed that the

mentor/mentee relationship was helpful beyond the freshman year.

\begin{tabular}{|c|c|c|c|c|c|c|}
\hline $\begin{array}{l}\text { Glynn 2006, } \\
\text { Ireland }\end{array}$ & $\begin{array}{l}\text { Subject: patient } \\
\text { communication } \\
\text { Tutors: M5 } \\
\text { Tutees: M2 }\end{array}$ & $\begin{array}{l}\text { Process of } \\
\text { peer-assisted learning } \\
\text { and identification of } \\
\text { strengths and } \\
\text { weaknesses in a } \\
\text { peer-tutoring program }\end{array}$ & $\begin{array}{l}\text { Peer Tutors ( } 2) \\
\text { and peer learners } \\
(14)\end{array}$ & $\begin{array}{l}\text { Evaluation of one } \\
\text { peer-assisted } \\
\text { learning session. } \\
\text { Data collected from } \\
\text { semi-structured } \\
\text { interviews from } \\
\text { tutors and tutees } \\
\text { prior to and post } \\
\text { session. }\end{array}$ & $\begin{array}{l}\text { Interviews demonstrated that } \\
\text { peer tutoring created a safe } \\
\text { learning environment that } \\
\text { facilitated a growth of } \\
\text { confidence in both learner } \\
\text { and tutor, helped foster } \\
\text { education exchange between } \\
\text { tutor and tutee, and that } \\
\text { communication and learning } \\
\text { was taking place freely and } \\
\text { on a number of different } \\
\text { levels between tutors and } \\
\text { learners. }\end{array}$ & $\begin{array}{l}\text { Only looked at the } \\
\text { process of peer assisted } \\
\text { learning, did not aim to } \\
\text { quantify any outcome } \\
\text { data } \\
\text { Data collected was } \\
\text { purely qualitative } \\
\text { Based on one session } \\
\text { Sample size small }\end{array}$ \\
\hline $\begin{array}{l}\text { Buckley, 2007, } \\
\text { United Kingdom }\end{array}$ & $\begin{array}{l}\text { Subject: clinical } \\
\text { examination skills } \\
\text { Tutors: M5 } \\
\text { Tutees: M3 }\end{array}$ & $\begin{array}{l}\text { Effects of } \\
\text { participation in a } \\
\text { cross-year peer } \\
\text { tutoring program in } \\
\text { clinical examination } \\
\text { skills on volunteer } \\
\text { tutors' own skills and } \\
\text { on their attitudes } \\
\text { towards teachers and } \\
\text { teaching. }\end{array}$ & Peer tutors (94) & $\begin{array}{l}\text { Questionnaires } \\
\text { completed by } \\
\text { volunteer M5 tutors } \\
\text { at the start of the } \\
\text { program after they } \\
\text { had planned and } \\
\text { delivered their } \\
\text { small group } \\
\text { sessions. }\end{array}$ & $\begin{array}{l}\text { Tutors reported that taking } \\
\text { part in program had } \\
\text { enhanced practical teaching } \\
\text { skills and confidence in } \\
\text { speaking to groups. Reported } \\
\text { tutoring increased the } \\
\text { likelihood that teaching } \\
\text { would be a major part of } \\
\text { their career and that they } \\
\text { would undertake further } \\
\text { teacher training }\end{array}$ & $\begin{array}{l}\text { Explored only the views } \\
\text { of volunteer tutors } \\
\text { Did not receive survey } \\
\text { responses from all tutors } \\
\text { Did not look at affect on } \\
\text { tutees } \\
\text { No discussion of } \\
\text { whether those who } \\
\text { participated in program } \\
\text { performed better }\end{array}$ \\
\hline $\begin{array}{l}\text { Weyrich, 2009, } \\
\text { Germany }\end{array}$ & $\begin{array}{l}\text { Subject: clinical } \\
\text { procedural skills } \\
\text { Tutors: M4 \& M5 } \\
\text { Tutees: M3 }\end{array}$ & $\begin{array}{l}\text { If peer-assisted } \\
\text { learning is effective } \\
\text { in technical skills } \\
\text { training in a skills lab } \\
\text { setting and if PAL is } \\
\text { equally as effective as } \\
\text { faculty staff-led } \\
\text { training for M3. }\end{array}$ & $\begin{array}{l}\text { Students tutored } \\
\text { by peers (31) } \\
\text { Students tutored } \\
\text { by faculty (28) } \\
\text { Students that } \\
\text { received no } \\
\text { tutoring (30) }\end{array}$ & $\begin{array}{l}\text { Directly after } \\
\text { receiving } \\
\text { PAL-assisted, } \\
\text { faculty-led or no } \\
\text { skills lab training, } \\
\text { students were } \\
\text { assessed using an } \\
\text { OSCE. } \\
\text { Independently rated } \\
\text { by two clinically } \\
\text { experienced video } \\
\text { assessors who were } \\
\text { blind to both the } \\
\text { aim of the study } \\
\text { and its design. }\end{array}$ & $\begin{array}{l}\text { Based on binary checklist } \\
\text { ratings, both PAL and } \\
\text { faculty-led students scored } \\
\text { significantly higher in the } \\
\text { OSCE than the non-trained } \\
\text { control group. There was no } \\
\text { significant difference } \\
\text { between the PAL group and } \\
\text { the faculty-led group with } \\
\text { respect to OSCE binary } \\
\text { checklist ratings. }\end{array}$ & $\begin{array}{l}\text { Explored very specific } \\
\text { technical skill: are } \\
\text { results generalizable to } \\
\text { other learning } \\
\text { objectives? } \\
\text { Sample size small to } \\
\text { determine difference } \\
\text { between two } \\
\text { intervention groups } \\
\text { Tutors selected, trained } \\
\text { extensively }\end{array}$ \\
\hline Perkins, 2002, UK & $\begin{array}{l}\text { Subject: } \\
\text { resuscitation } \\
\text { training } \\
\text { Tutors: M2 } \\
\text { Tutees: M1, D1, } \\
\text { PT1, and } 1^{\text {st }} \text { year } \\
\text { nursing students } \\
\text { (N1). }\end{array}$ & $\begin{array}{l}\text { Efficacy of a peer-led } \\
\text { tuition model for } \\
\text { training healthcare } \\
\text { students in basic life } \\
\text { support compared to } \\
\text { tuition delivered by } \\
\text { clinical tutors. }\end{array}$ & $\begin{array}{l}\text { Students tutored } \\
\text { by peers (66) } \\
\text { Students tutored } \\
\text { by faculty (62) }\end{array}$ & $\begin{array}{l}\text { Practical skills } \\
\text { tested by blinded } \\
\text { examiners and } \\
\text { knowledge by } \\
\text { multiple choice } \\
\text { exam. Students } \\
\text { were asked how } \\
\text { they rated the } \\
\text { quality of teaching } \\
\text { using a visual } \\
\text { analogue score. } \\
\text { Instructor } \\
\text { reliability was } \\
\text { measured by } \\
\text { recording the } \\
\text { attendance of } \\
\text { instructors at the } \\
\text { training sessions. }\end{array}$ & $\begin{array}{l}\text { Students taught by their } \\
\text { peers were significantly } \\
\text { more likely to be successful } \\
\text { in the end-of-course practical } \\
\text { examination than those } \\
\text { taught by clinical staff. The } \\
\text { student instructors were also } \\
\text { found to be more reliable } \\
\text { than clinical staff at } \\
\text { attending the training } \\
\text { sessions. There was no } \\
\text { significant difference in } \\
\text { multiple-choice question } \\
\text { results or student satisfaction } \\
\text { rates }\end{array}$ & $\begin{array}{l}\text { Explored very specific } \\
\text { technical skill: are } \\
\text { results generalizable to } \\
\text { other learning } \\
\text { objectives? } \\
\text { Students had to receive } \\
\text { training to become } \\
\text { tutors. }\end{array}$ \\
\hline $\begin{array}{l}\text { Tolsgaard, 2007, } \\
\text { Denmark }\end{array}$ & $\begin{array}{l}\text { Subject: clinical } \\
\text { procedural skills } \\
\text { Tutors: Senior }\end{array}$ & $\begin{array}{l}\text { Quality of procedural } \\
\text { skills teaching of } \\
\text { student teachers and } \\
\text { clinical associate }\end{array}$ & $\begin{array}{l}\text { Students tutored } \\
\text { by peers (31) } \\
\text { Students tutored }\end{array}$ & $\begin{array}{l}\text { Participants } \\
\text { pre-tested and } \\
\text { post-tested on } \\
\text { practical }\end{array}$ & $\begin{array}{l}\text { There was no significant } \\
\text { difference between groups in } \\
\text { learning outcome regarding } \\
\text { procedure } 1 \text { or in any of the }\end{array}$ & $\begin{array}{l}\text { Using the same set of } \\
\text { tests for the pre and post } \\
\text { testing could have } \\
\text { induced a learning effect }\end{array}$ \\
\hline
\end{tabular}




\begin{tabular}{|c|c|c|c|c|c|c|}
\hline & $\begin{array}{l}\text { medical students } \\
\text { Tutees: M1 }\end{array}$ & $\begin{array}{l}\text { professors in terms of } \\
\text { participants' technical } \\
\text { skills, knowledge and } \\
\text { satisfaction with the } \\
\text { teaching of two } \\
\text { procedural skills. }\end{array}$ & by faculty (28) & $\begin{array}{l}\text { (manikin) and } \\
\text { written tests (short } \\
\text { answer). The } \\
\text { practical and } \\
\text { written tests were } \\
\text { scored and } \\
\text { reviewed by two } \\
\text { blinded external } \\
\text { clinical experts in } \\
\text { each of the skills. } \\
\text { After the post-test } \\
\text { the participants } \\
\text { were asked to } \\
\text { indicate their } \\
\text { satisfaction with } \\
\text { the teaching on an } \\
\text { evaluation. }\end{array}$ & $\begin{array}{l}\text { two written tests. } \\
\text { Regarding practical } \\
\text { performance of procedure 2, } \\
\text { the group taught by student } \\
\text { teachers had significant } \\
\text { higher mean difference in } \\
\text { post- minus pre-test score } \\
\text { compared to the group taught } \\
\text { by associate professors. } \\
\text { Participants rated the } \\
\text { teaching of the student } \\
\text { teachers significantly higher } \\
\text { than that of associate } \\
\text { professors on three } \\
\text { statements. }\end{array}$ & $\begin{array}{l}\text { No control group } \\
\text { Only studied two basic } \\
\text { clinical skills- not } \\
\text { necessarily transferable } \\
\text { to more technical skills }\end{array}$ \\
\hline $\begin{array}{l}\text { Nimmo 2007, } \\
\text { USA }\end{array}$ & $\begin{array}{l}\text { Subject: } \\
\text { prosthodontics and } \\
\text { occlusion } \\
\text { Tutors: D3 \& D4 } \\
\text { Tutees: D2 }\end{array}$ & $\begin{array}{l}\text { Dental students as } \\
\text { instructors in } \\
\text { preclinical } \\
\text { prosthodontics and } \\
\text { occlusion courses, } \\
\text { providing one-on-one } \\
\text { instruction and } \\
\text { evaluation of daily } \\
\text { work for the D2 } \\
\text { students. }\end{array}$ & $\begin{array}{l}\text { Students } \\
\text { integrated as } \\
\text { faculty in two D2 } \\
\text { courses (80) }\end{array}$ & $\begin{array}{l}\text { Evaluation by the } \\
\text { D2 students of } \\
\text { full-time faculty } \\
\text { and student } \\
\text { instructors at the } \\
\text { end of the course, } \\
\text { consisting of an } \\
\text { instructor quality } \\
\text { score, a survey of } \\
\text { student instructors } \\
\text { about their } \\
\text { experience and a } \\
\text { course debriefing } \\
\text { with selected D2 } \\
\text { students. }\end{array}$ & $\begin{array}{l}\text { Analysis of the evaluation } \\
\text { mean scores indicates there } \\
\text { is no evidence to suggest that } \\
\text { the mean instructor-quality } \\
\text { scores of student instructors } \\
\text { are lower than that of } \\
\text { full-time faculty instructors, } \\
\text { and there is weak evidence } \\
\text { to suggest that the mean } \\
\text { instructor-quality scores of } \\
\text { student instructors is actually } \\
\text { higher than that of the } \\
\text { faculty. }\end{array}$ & $\begin{array}{l}\text { Tutors could have } \\
\text { received higher } \\
\text { perceived marks because } \\
\text { they were not involved } \\
\text { with grading students } \\
\text { Study did not have } \\
\text { measured outcomes of } \\
\text { students taught by only } \\
\text { faculty vs students } \\
\text { taught by peer + faculty } \\
\text { combination }\end{array}$ \\
\hline $\begin{array}{l}\text { Nimmo 2008, } \\
\text { USA }\end{array}$ & $\begin{array}{l}\text { Subject: } \\
\text { Prosthodontics } \\
\text { Tutors: D4 } \\
\text { Tutees: D2 }\end{array}$ & $\begin{array}{l}\text { Use of senior dental } \\
\text { students as instructors } \\
\text { in preclinical } \\
\text { prosthodontics } \\
\text { courses for D2 from } \\
\text { the perspective of } \\
\text { preclinical } \\
\text { performance on } \\
\text { graded exercises. }\end{array}$ & $\begin{array}{l}\text { Two groups of } \\
\text { students ( } 34 \text { and } \\
48 \text { ) alternated } \\
\text { between faculty } \\
\text { and student } \\
\text { teaching }\end{array}$ & $\begin{array}{l}\text { A statistical } \\
\text { analysis was } \\
\text { performed on the } \\
\text { graded projects for } \\
\text { the two courses, } \\
\text { comparing the } \\
\text { effect of type of } \\
\text { instructor }\end{array}$ & $\begin{array}{l}\text { The results indicate no } \\
\text { significant difference for all } \\
\text { groups. }\end{array}$ & $\begin{array}{l}\text { No monitoring of } \\
\text { instruction or interaction } \\
\text { outside of schooled lab } \\
\text { sessions } \\
\text { Grade inflation may } \\
\text { have obscured some } \\
\text { grading variables } \\
\text { Results may not apply } \\
\text { directly to other } \\
\text { preclinical courses or } \\
\text { disciplines }\end{array}$ \\
\hline $\begin{array}{l}\text { Haj-Ali, 2007, } \\
\text { USA }\end{array}$ & $\begin{array}{l}\text { Subject: } \\
\text { morphology/ } \\
\text { Occlusion } \\
\text { Tutors: D4 } \\
\text { Tutees: D1 }\end{array}$ & $\begin{array}{l}\text { Whether senior dental } \\
\text { students could serve } \\
\text { as effective } \\
\text { instructors in a } \\
\text { two-semester } \\
\text { preclinical laboratory } \\
\text { course and whether } \\
\text { such teaching } \\
\text { experience could } \\
\text { enhance their interest } \\
\text { in academics as a } \\
\text { future career. }\end{array}$ & $\begin{array}{l}\text { D1 students were } \\
\text { randomly } \\
\text { assigned so that } \\
\text { each student was } \\
\text { instructed by a } \\
\text { faculty member } \\
\text { in one semester } \\
\text { and a D4 in the } \\
\text { other semester. } \\
\text { (95) }\end{array}$ & $\begin{array}{l}\text { Course evaluation } \\
\text { forms completed by } \\
\text { the first-year dental } \\
\text { students at the end } \\
\text { of each semester; a } \\
\text { comparison of } \\
\text { students' } \\
\text { performances in } \\
\text { each course } \\
\text { determined by } \\
\text { faculty instructors } \\
\text { and D4s; and the } \\
\text { D4s' self-report of } \\
\text { their teaching } \\
\text { experiences. }\end{array}$ & $\begin{array}{l}\text { Results showed no } \\
\text { significant difference } \\
\text { between the performance of } \\
\text { D4s and faculty instructors } \\
\text { in all criteria evaluated. } \\
\text { Furthermore, there was no } \\
\text { significant difference } \\
\text { between the performance of } \\
\text { students instructed by faculty } \\
\text { members and those } \\
\text { instructed by D4s in either } \\
\text { semester. Despite the fact } \\
\text { that such experience seemed } \\
\text { to have minimal influence on } \\
\text { students' decision to } \\
\text { consider academics as a } \\
\text { future career, D4s do seem to } \\
\text { provide effective instruction } \\
\text { and thereby can serve to } \\
\text { compensate for faculty } \\
\text { shortages. }\end{array}$ & $\begin{array}{l}\text { Some non-response bias } \\
\text { due to lack of full } \\
\text { student participation in } \\
\text { survey } \\
\text { Results may not apply } \\
\text { directly to other } \\
\text { preclinical courses or } \\
\text { disciplines } \\
\text { D4 tutors highly } \\
\text { selected and instructed } \\
\text { by faculty }\end{array}$ \\
\hline $\begin{array}{l}\text { Author Year } \\
\text { Country }\end{array}$ & $\begin{array}{l}\text { Subject Matter } \\
\text { and Participants }\end{array}$ & $\begin{array}{l}\text { Factors Examined } \\
\text { by Study }\end{array}$ & $\begin{array}{l}\text { Groups } \\
\text { evaluated (n) }\end{array}$ & $\begin{array}{l}\text { Evaluation } \\
\text { Methods }\end{array}$ & Results & Limitations \\
\hline Haist 1998 USA & $\begin{array}{l}\text { Tutors: 4th year } \\
\text { medical students } \\
\text { (M4) } \\
\text { Tutees: 1st year }\end{array}$ & $\begin{array}{l}\text { Student performance } \\
\text { on written and } \\
\text { practical examination } \\
\text { when tutored by peers } \\
\text { or faculty. } \\
\text { Student ratings of }\end{array}$ & $\begin{array}{l}\text { Students tutored } \\
\text { by peers or staff } \\
\text { (93 students } \\
\text { overall) }\end{array}$ & $\begin{array}{l}\text { Mean scores } \\
\text { (adjusted based on } \\
\text { GPA) on a written } \\
\text { test and an } \\
\text { observed hour-long } \\
\text { standard patient } \\
\text { examination. }\end{array}$ & $\begin{array}{l}\text { Standardized patient exam } \\
\text { scores not significantly } \\
\text { different. }\end{array}$ & $\begin{array}{l}\text { Very basic skills taught } \\
\text { Student preceptors } \\
\text { selected based on }\end{array}$ \\
\hline
\end{tabular}




\begin{tabular}{|c|c|c|c|c|c|c|}
\hline & $\begin{array}{l}\text { medical students } \\
\text { (M1) }\end{array}$ & $\begin{array}{l}\text { faculty vs peer } \\
\text { preceptors. } \\
\text { Impact of program on } \\
\text { peer tutors. }\end{array}$ & & $\begin{array}{l}\text { Students rated } \\
\text { preceptors at end of } \\
\text { course. }\end{array}$ & $\begin{array}{l}\text { M1 rated peer preceptors } \\
\text { higher in all specific items. } \\
\text { M4 preceptors rated their } \\
\text { experiences very favorably. }\end{array}$ & academic success \\
\hline & & & & $\begin{array}{l}\text { Student preceptors } \\
\text { rated experience. }\end{array}$ & & \\
\hline Haist 1997 USA & $\begin{array}{l}\text { Subject: physical } \\
\text { examination } \\
\text { Tutors: M4 } \\
\text { Tutees: M1 }\end{array}$ & $\begin{array}{l}\text { Student performance } \\
\text { on written and } \\
\text { practical examination } \\
\text { when tutored by peers } \\
\text { or faculty. } \\
\text { Student ratings of } \\
\text { faculty vs peer } \\
\text { preceptors. } \\
\text { Impact of program on } \\
\text { peer tutors. }\end{array}$ & $\begin{array}{l}\text { Students tutored } \\
\text { by faculty (64) }\end{array}$ & $\begin{array}{l}\text { Mean scores on a } \\
\text { written exam and a } \\
\text { practical } \\
\text { examination } \\
\text { (evaluated by } \\
\text { standardized } \\
\text { patients). } \\
\text { Students rated } \\
\text { preceptors at end of } \\
\text { course. } \\
\text { Student preceptors } \\
\text { rated experience. }\end{array}$ & $\begin{array}{l}\text { Scores on a written and } \\
\text { practical examination were } \\
\text { not significantly different. } \\
\text { No significant differences in } \\
\text { how students rated peer } \\
\text { preceptors vs faculty } \\
\text { preceptors. } \\
\text { M4 preceptors rated their } \\
\text { experiences very favorably. }\end{array}$ & $\begin{array}{l}\text { Done at single } \\
\text { institution } \\
\text { Very basic skills taught } \\
\text { Student preceptors } \\
\text { selected based on } \\
\text { academic success }\end{array}$ \\
\hline Barnes 1978 USA & $\begin{array}{l}\text { Subject: medical } \\
\text { history, physical } \\
\text { examination } \\
\text { Tutors: M4 } \\
\text { Tutees: M2 }\end{array}$ & $\begin{array}{l}\text { Student performance } \\
\text { on practical } \\
\text { examination when } \\
\text { tutored by peers or } \\
\text { faculty. } \\
\text { Student ratings of } \\
\text { faculty vs peer } \\
\text { preceptors. } \\
\text { Peer tutor perceived } \\
\text { ability and impact of } \\
\text { program. }\end{array}$ & $\begin{array}{l}\text { Students tutored } \\
\text { by peers (13) } \\
\text { Students tutored } \\
\text { by faculty (14) }\end{array}$ & $\begin{array}{l}\text { Independent, } \\
\text { blinded trained } \\
\text { reviewer judged } \\
\text { performance on } \\
\text { history and } \\
\text { physical exam. } \\
\text { Students rated } \\
\text { preceptors at } \\
\text { beginning and end } \\
\text { of course. } \\
\text { Student tutors rated } \\
\text { experience. }\end{array}$ & $\begin{array}{l}\text { No significant differences in } \\
\text { the performances. } \\
\text { At both beginning and end } \\
\text { evaluations students rated } \\
\text { student tutors better at giving } \\
\text { helpful suggestions. } \\
\text { M4 preceptors rated their } \\
\text { experiences very favorably } \\
\text { and were confident in their } \\
\text { ability to serve as effective } \\
\text { tutors. }\end{array}$ & $\begin{array}{l}\begin{array}{l}\text { Done at single } \\
\text { institution }\end{array} \\
\text { Relatively small sample } \\
\text { size }\end{array}$ \\
\hline $\begin{array}{l}\text { Trevino and } \\
\text { Eiland, } 1980 \text { USA }\end{array}$ & $\begin{array}{l}\text { Subject: various } \\
\text { basic science } \\
\text { courses } \\
\text { Tutors: graduate } \\
\text { students, advanced } \\
\text { medical students } \\
\text { Tutees: M1, M2 }\end{array}$ & $\begin{array}{l}\text { If peer tutorial } \\
\text { program improves } \\
\text { test scores of } \\
\text { poor-performing } \\
\text { students. }\end{array}$ & $\begin{array}{l}\text { Same students } \\
\text { before and after } \\
\text { tutoring was } \\
\text { introduced (55) }\end{array}$ & $\begin{array}{l}\text { Average course } \\
\text { grade (method of } \\
\text { assessment not } \\
\text { mentioned) }\end{array}$ & $\begin{array}{l}\text { Average course grades } \\
\text { higher after tutoring. }\end{array}$ & $\begin{array}{l}\text { Only students } \\
\text { performing poorly } \\
\text { tutored }\end{array}$ \\
\hline Lake, 1999, USA & $\begin{array}{l}\text { Subject: physiology } \\
\text { Tutors: 5th year } \\
\text { physical therapy } \\
\text { students (PT5) } \\
\text { Tutees: PT3 }\end{array}$ & $\begin{array}{l}\text { If peer tutoring } \\
\text { program helps } \\
\text { improve performance } \\
\text { as students move } \\
\text { from introductory to } \\
\text { advanced course. } \\
\text { Junior students views } \\
\text { on peer tutoring }\end{array}$ & $\begin{array}{l}\text { Students enrolled } \\
\text { in the course } \\
\text { when peer } \\
\text { tutoring was } \\
\text { available (69) } \\
\text { Students enrolled } \\
\text { in the course } \\
\text { when peer } \\
\text { tutoring wasn't } \\
\text { available (45) }\end{array}$ & $\begin{array}{l}\text { Difference between } \\
\text { the introductory } \\
\text { course grade and } \\
\text { the advanced } \\
\text { course grade; Letter } \\
\text { grades converted } \\
\text { into points on an } 11 \\
\text { point system. } \\
\text { Students' } \\
\text { perceptions } \\
\text { measured by two } \\
\text { questions as part of } \\
\text { the end-of-term } \\
\text { student course } \\
\text { evaluation. }\end{array}$ & $\begin{array}{l}\text { Those enrolled when peer } \\
\text { tutoring was available had a } \\
\text { smaller decline in course } \\
\text { grade. } \\
\text { Those who attended the } \\
\text { tutoring sessions rated their } \\
\text { perceived value of the } \\
\text { tutoring sessions highly and } \\
\text { expressed strong interest in } \\
\text { having tutoring sessions for } \\
\text { future courses. }\end{array}$ & $\begin{array}{l}\text { Compares two different } \\
\text { semesters of students } \\
\text { Does not factor in if } \\
\text { exams were identical }\end{array}$ \\
\hline $\begin{array}{l}\text { Matthes, 2002, } \\
\text { Germany }\end{array}$ & $\begin{array}{l}\text { Subject: problem- } \\
\text { based learning } \\
\text { (PBL) in } \\
\text { pharmacology } \\
\text { Tutors: M4 or more } \\
\text { advanced medical } \\
\text { students } \\
\text { Tutees: M3 }\end{array}$ & $\begin{array}{l}\text { Whether peer vs } \\
\text { faculty tutoring in } \\
\text { problem based } \\
\text { learning affects the } \\
\text { results of process } \\
\text { evaluation by } \\
\text { participants or their } \\
\text { learning outcome }\end{array}$ & $\begin{array}{l}\text { Students tutored } \\
\text { by peers, junior } \\
\text { faculty or senior } \\
\text { faculty (787 } \\
\text { students overall) }\end{array}$ & $\begin{array}{l}\text { Mean exam scores } \\
\text { (multiple choice } \\
\text { questions, short- } \\
\text { essay) }\end{array}$ & $\begin{array}{l}\text { Mean exam scores not } \\
\text { significantly different. }\end{array}$ & $\begin{array}{l}\text { Traditional exam may } \\
\text { not be reflective } \\
\text { evaluation of } \\
\text { effectiveness of PBL } \\
\text { Student tutors may make } \\
\text { shortcuts that direct } \\
\text { learning activity toward } \\
\text { exam-related objectives }\end{array}$ \\
\hline $\begin{array}{l}\text { Nestel and Kidd, } \\
\text { 2003, United } \\
\text { Kingdom }\end{array}$ & $\begin{array}{l}\text { Subject: } \\
\text { interviewing } \\
\text { patients } \\
\text { Tutors: M3 }\end{array}$ & $\begin{array}{l}\text { Impact on first-year } \\
\text { medical students of } \\
\text { peer tutoring in } \\
\text { patient-centered } \\
\text { interviewing. }\end{array}$ & $\begin{array}{l}\text { Students tutored } \\
\text { by peers (20) } \\
\text { Students tutored } \\
\text { by faculty (19) }\end{array}$ & $\begin{array}{l}\text { Mean rating of } \\
\text { interviewing skills } \\
\text { by independent } \\
\text { assessors and } \\
\text { simulated patient's }\end{array}$ & $\begin{array}{l}\text { No differences seen in the } \\
\text { ratings given by the } \\
\text { independent assessors or } \\
\text { simulated patients. }\end{array}$ & $\begin{array}{l}\text { Peer tutors contributed } \\
\text { to just one of six } \\
\text { sessions } \\
\text { Period between the }\end{array}$ \\
\hline
\end{tabular}




\begin{tabular}{|c|c|c|c|}
\hline Tutees: M1 & $\begin{array}{l}\text { rating of student's } \\
\text { interviewing skills } \\
\text { and satisfaction } \\
\text { with the interview. } \\
\text { First-year students' } \\
\text { experiences of the } \\
\text { simulated patient } \\
\text { sessions were } \\
\text { evaluated } \\
\text { immediately } \\
\text { following session. }\end{array}$ & $\begin{array}{l}\text { Significant difference for } \\
\text { patient satisfaction. } \\
\text { More students in groups } \\
\text { facilitated by medical } \\
\text { teachers reported completely } \\
\text { meeting learning objectives } \\
\text { and practiced completely } \\
\text { effective teaching } \\
\text { techniques. }\end{array}$ & $\begin{array}{l}\text { session and the } \\
\text { interviewing assessment } \\
\text { Single cohort of students }\end{array}$ \\
\hline
\end{tabular}

\section{Rund, 1977, Subject: physical} USA

diagnosis
Tutors: final year medical students

Tutees: M1 taught

by students; M2

taught by faculty
If a student-taught course in physical diagnosis was as effective as a traditional faculty-taught course
M1 who volunteered to be taught by peers (17)

M2 taught by faculty the year prior who volunteered to take the exam (17)

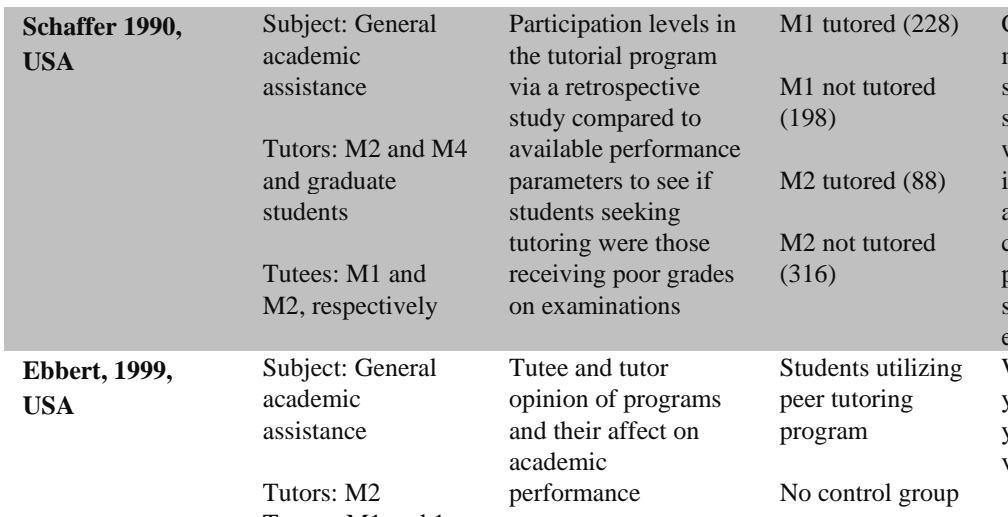

Tutees: M1 and 1st year dental students (D1)
Performance was similar on all assessment methods, except M2 students performed better on a portion of the multiple choice test covering vocabulary.
Students were chosen randomly from volunteers and not from entire class

Students knew they were an experimental group
Correlation was made between students who sought tutoring and who had been identified by academic committee as performing below satisfactory on examinations Written surveys of year-one dental and year-two co-op volunteers

\section{A statistically significant relationship was found to exist between poor performance on examinations and participation in the tutorial program for both the first and second-year medical students. \\ Student responses were generally positive especially to new teaching formats.

\author{
Other factors involved \\ in seeking tutoring \\ besides academic \\ performance \\ Retrospective and not \\ controlled \\ Qualitative study with \\ no quantitative evidence \\ of efficacy
} M1 and D1 report program good for basic science concepts, tips for studying and test taking, and "surviving" first years of school. M2 reported better teaching skills, more collegial interactions, and reviewing for USMLE step 1 material

\begin{tabular}{|c|c|c|c|c|c|c|}
\hline $\begin{array}{l}\text { Goodfellow \& } \\
\text { Schofield, 2001, } \\
\text { United Kingdom }\end{array}$ & $\begin{array}{l}\text { Subject: respiratory } \\
\text { examination } \\
\text { Tutors: M4 } \\
\text { Tutees: M3 }\end{array}$ & $\begin{array}{l}\text { Success of peer } \\
\text { tutorials }\end{array}$ & $\begin{array}{l}\text { Students utilizing } \\
\text { peer tutoring } \\
\text { program (49) }\end{array}$ & $\begin{array}{l}\text { Evaluation } \\
\text { questionnaire } \\
\text { completed by } \\
\text { students who } \\
\text { attended peer } \\
\text { tutorials using a } 10 \\
\text { centimeter visual } \\
\text { analogue scale to } \\
\text { assess responses. }\end{array}$ & $\begin{array}{l}\text { Students found the tutorials } \\
\text { useful. Students were found } \\
\text { to feel significantly more } \\
\text { capable performing a } \\
\text { respiratory examination after } \\
\text { the tutorial. }\end{array}$ & $\begin{array}{l}\text { Only one session given } \\
\text { No comparison group to } \\
\text { those who did not } \\
\text { receive tutoring } \\
\text { Small cohort }\end{array}$ \\
\hline Lopez, 2010, USA & $\begin{array}{l}\text { Subject: General } \\
\text { academic } \\
\text { assistance } \\
\text { Tutors: D2 } \\
\text { Tutees: D1 }\end{array}$ & $\begin{array}{l}\text { Peer mentoring } \\
\text { program effectiveness } \\
\text { and relevance to } \\
\text { current students }\end{array}$ & $\begin{array}{l}\text { Students who } \\
\text { participate in } \\
\text { mentoring } \\
\text { program (256) }\end{array}$ & $\begin{array}{l}\text { Evaluation by } \\
\text { survey. Questions } \\
\text { regarding benefits } \\
\text { of peer mentoring } \\
\text { program, } \\
\text { qualifications for } \\
\text { mentors and } \\
\text { preparation for } \\
\text { mentorship, and } \\
\text { time commitment }\end{array}$ & $\begin{array}{l}70 \% \text { of respondents from all } \\
\text { classes agreed that having a } \\
\text { mentor during their first year } \\
\text { helped them transition to } \\
\text { dental school, and } 58 \% \\
\text { agreed that the } \\
\text { mentor/mentee relationship } \\
\text { was helpful beyond the } \\
\text { freshman year. }\end{array}$ & $\begin{array}{l}\begin{array}{l}\text { No quantitative } \\
\text { evaluation of academic } \\
\text { performance }\end{array} \\
\text { No control group of } \\
\text { students who did not } \\
\text { utilize program. }\end{array}$ \\
\hline Glynn 2006, & Subject: patient & Process of & Peer Tutors (2) & Evaluation of one & Interviews demonstrated that & Only looked at the \\
\hline
\end{tabular}

No report on number of students or number of tutors, tutoring hours

No details on survey questions or quantitative survey scale results

No comparison group to those who did not

small cohort 


\begin{tabular}{|c|c|c|c|c|c|c|}
\hline Ireland & $\begin{array}{l}\text { communication } \\
\text { Tutors: M5 } \\
\text { Tutees: M2 }\end{array}$ & $\begin{array}{l}\text { peer-assisted learning } \\
\text { and identification of } \\
\text { strengths and } \\
\text { weaknesses in a } \\
\text { peer-tutoring program }\end{array}$ & $\begin{array}{l}\text { and peer learners } \\
\text { (14) }\end{array}$ & $\begin{array}{l}\text { peer-assisted } \\
\text { learning session. } \\
\text { Data collected from } \\
\text { semi-structured } \\
\text { interviews from } \\
\text { tutors and tutees } \\
\text { prior to and post } \\
\text { session. }\end{array}$ & $\begin{array}{l}\text { peer tutoring created a safe } \\
\text { learning environment that } \\
\text { facilitated a growth of } \\
\text { confidence in both learner } \\
\text { and tutor, helped foster } \\
\text { education exchange between } \\
\text { tutor and tutee, and that } \\
\text { communication and learning } \\
\text { was taking place freely and } \\
\text { on a number of different } \\
\text { levels between tutors and } \\
\text { learners. }\end{array}$ & 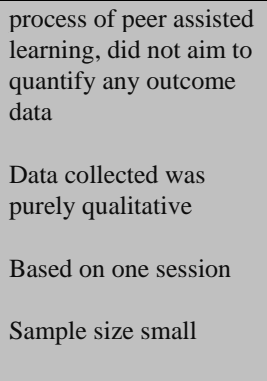 \\
\hline $\begin{array}{l}\text { Buckley, 2007, } \\
\text { United Kingdom }\end{array}$ & $\begin{array}{l}\text { Subject: clinical } \\
\text { examination skills } \\
\text { Tutors: M5 } \\
\text { Tutees: M3 }\end{array}$ & $\begin{array}{l}\text { Effects of } \\
\text { participation in a } \\
\text { cross-year peer } \\
\text { tutoring program in } \\
\text { clinical examination } \\
\text { skills on volunteer } \\
\text { tutors' own skills and } \\
\text { on their attitudes } \\
\text { towards teachers and } \\
\text { teaching. }\end{array}$ & Peer tutors (94) & $\begin{array}{l}\text { Questionnaires } \\
\text { completed by } \\
\text { volunteer M5 tutors } \\
\text { at the start of the } \\
\text { program after they } \\
\text { had planned and } \\
\text { delivered their } \\
\text { small group } \\
\text { sessions. }\end{array}$ & $\begin{array}{l}\text { Tutors reported that taking } \\
\text { part in program had } \\
\text { enhanced practical teaching } \\
\text { skills and confidence in } \\
\text { speaking to groups. Reported } \\
\text { tutoring increased the } \\
\text { likelihood that teaching } \\
\text { would be a major part of } \\
\text { their career and that they } \\
\text { would undertake further } \\
\text { teacher training }\end{array}$ & $\begin{array}{l}\begin{array}{l}\text { Explored only the views } \\
\text { of volunteer tutors }\end{array} \\
\text { Did not receive survey } \\
\text { responses from all tutors } \\
\text { Did not look at affect on } \\
\text { tutees } \\
\text { No discussion of } \\
\text { whether those who } \\
\text { participated in program } \\
\text { performed better }\end{array}$ \\
\hline $\begin{array}{l}\text { Weyrich, 2009, } \\
\text { Germany }\end{array}$ & $\begin{array}{l}\text { Subject: clinical } \\
\text { procedural skills } \\
\text { Tutors: M4 \& M5 } \\
\text { Tutees: M3 }\end{array}$ & $\begin{array}{l}\text { If peer-assisted } \\
\text { learning is effective } \\
\text { in technical skills } \\
\text { training in a skills lab } \\
\text { setting and if PAL is } \\
\text { equally as effective as } \\
\text { faculty staff-led } \\
\text { training for M3. }\end{array}$ & $\begin{array}{l}\text { Students tutored } \\
\text { by peers (31) } \\
\text { Students tutored } \\
\text { by faculty (28) } \\
\text { Students that } \\
\text { received no } \\
\text { tutoring (30) }\end{array}$ & $\begin{array}{l}\text { Directly after } \\
\text { receiving } \\
\text { PAL-assisted, } \\
\text { faculty-led or no } \\
\text { skills lab training, } \\
\text { students were } \\
\text { assessed using an } \\
\text { OSCE. } \\
\text { Independently rated } \\
\text { by two clinically } \\
\text { experienced video } \\
\text { assessors who were } \\
\text { blind to both the } \\
\text { aim of the study } \\
\text { and its design. }\end{array}$ & $\begin{array}{l}\text { Based on binary checklist } \\
\text { ratings, both PAL and } \\
\text { faculty-led students scored } \\
\text { significantly higher in the } \\
\text { OSCE than the non-trained } \\
\text { control group. There was no } \\
\text { significant difference } \\
\text { between the PAL group and } \\
\text { the faculty-led group with } \\
\text { respect to OSCE binary } \\
\text { checklist ratings. }\end{array}$ & $\begin{array}{l}\text { Explored very specific } \\
\text { technical skill: are } \\
\text { results generalizable to } \\
\text { other learning } \\
\text { objectives? } \\
\text { Sample size small to } \\
\text { determine difference } \\
\text { between two } \\
\text { intervention groups } \\
\text { Tutors selected, trained } \\
\text { extensively }\end{array}$ \\
\hline Perkins, 2002, UK & $\begin{array}{l}\text { Subject: } \\
\text { resuscitation } \\
\text { training } \\
\text { Tutors: M2 } \\
\text { Tutees: M1, D1, } \\
\text { PT1, and } 1^{\text {st }} \text { year } \\
\text { nursing students } \\
(\mathrm{N} 1) \text {. }\end{array}$ & $\begin{array}{l}\text { Efficacy of a peer-led } \\
\text { tuition model for } \\
\text { training healthcare } \\
\text { students in basic life } \\
\text { support compared to } \\
\text { tuition delivered by } \\
\text { clinical tutors. }\end{array}$ & $\begin{array}{l}\text { Students tutored } \\
\text { by peers (66) } \\
\text { Students tutored } \\
\text { by faculty (62) }\end{array}$ & $\begin{array}{l}\text { Practical skills } \\
\text { tested by blinded } \\
\text { examiners and } \\
\text { knowledge by } \\
\text { multiple choice } \\
\text { exam. Students } \\
\text { were asked how } \\
\text { they rated the } \\
\text { quality of teaching } \\
\text { using a visual } \\
\text { analogue score. } \\
\text { Instructor } \\
\text { reliability was } \\
\text { measured by } \\
\text { recording the } \\
\text { attendance of } \\
\text { instructors at the } \\
\text { training sessions. }\end{array}$ & $\begin{array}{l}\text { Students taught by their } \\
\text { peers were significantly } \\
\text { more likely to be successful } \\
\text { in the end-of-course practical } \\
\text { examination than those } \\
\text { taught by clinical staff. The } \\
\text { student instructors were also } \\
\text { found to be more reliable } \\
\text { than clinical staff at } \\
\text { attending the training } \\
\text { sessions. There was no } \\
\text { significant difference in } \\
\text { multiple-choice question } \\
\text { results or student satisfaction } \\
\text { rates }\end{array}$ & $\begin{array}{l}\text { Explored very specific } \\
\text { technical skill: are } \\
\text { results generalizable to } \\
\text { other learning } \\
\text { objectives? } \\
\text { Students had to receive } \\
\text { training to become } \\
\text { tutors. }\end{array}$ \\
\hline $\begin{array}{l}\text { Tolsgaard, 2007, } \\
\text { Denmark }\end{array}$ & $\begin{array}{l}\text { Subject: clinical } \\
\text { procedural skills } \\
\text { Tutors: Senior } \\
\text { medical students } \\
\text { Tutees: M1 }\end{array}$ & $\begin{array}{l}\text { Quality of procedural } \\
\text { skills teaching of } \\
\text { student teachers and } \\
\text { clinical associate } \\
\text { professors in terms of } \\
\text { participants' technical } \\
\text { skills, knowledge and } \\
\text { satisfaction with the } \\
\text { teaching of two } \\
\text { procedural skills. }\end{array}$ & $\begin{array}{l}\text { Students tutored } \\
\text { by peers (31) } \\
\text { Students tutored } \\
\text { by faculty (28) }\end{array}$ & $\begin{array}{l}\text { Participants } \\
\text { pre-tested and } \\
\text { post-tested on } \\
\text { practical } \\
\text { (manikin) and } \\
\text { written tests (short } \\
\text { answer). The } \\
\text { practical and } \\
\text { written tests were } \\
\text { scored and } \\
\text { reviewed by two } \\
\text { blinded external } \\
\text { clinical experts in } \\
\text { each of the skills. }\end{array}$ & $\begin{array}{l}\text { There was no significant } \\
\text { difference between groups in } \\
\text { learning outcome regarding } \\
\text { procedure } 1 \text { or in any of the } \\
\text { two written tests. } \\
\text { Regarding practical } \\
\text { performance of procedure } 2 \text {, } \\
\text { the group taught by student } \\
\text { teachers had significant } \\
\text { higher mean difference in } \\
\text { post- minus pre-test score } \\
\text { compared to the group taught } \\
\text { by associate professors. } \\
\text { Participants rated the }\end{array}$ & $\begin{array}{l}\text { Using the same set of } \\
\text { tests for the pre and post } \\
\text { testing could have } \\
\text { induced a learning effect } \\
\text { No control group } \\
\text { Only studied two basic } \\
\text { clinical skills- not } \\
\text { necessarily transferable } \\
\text { to more technical skills }\end{array}$ \\
\hline
\end{tabular}




\begin{tabular}{|c|c|c|c|c|c|c|}
\hline & & & & $\begin{array}{l}\text { After the post-test } \\
\text { the participants } \\
\text { were asked to } \\
\text { indicate their } \\
\text { satisfaction with } \\
\text { the teaching on an } \\
\text { evaluation. }\end{array}$ & $\begin{array}{l}\text { teaching of the student } \\
\text { teachers significantly higher } \\
\text { than that of associate } \\
\text { professors on three } \\
\text { statements. }\end{array}$ & \\
\hline $\begin{array}{l}\text { Nimmo 2007, } \\
\text { USA }\end{array}$ & $\begin{array}{l}\text { Subject: } \\
\text { prosthodontics and } \\
\text { occlusion } \\
\text { Tutors: D3 \& D4 } \\
\text { Tutees: D2 }\end{array}$ & $\begin{array}{l}\text { Dental students as } \\
\text { instructors in } \\
\text { preclinical } \\
\text { prosthodontics and } \\
\text { occlusion courses, } \\
\text { providing one-on-one } \\
\text { instruction and } \\
\text { evaluation of daily } \\
\text { work for the D2 } \\
\text { students. }\end{array}$ & $\begin{array}{l}\text { Students } \\
\text { integrated as } \\
\text { faculty in two D2 } \\
\text { courses (80) }\end{array}$ & $\begin{array}{l}\text { Evaluation by the } \\
\text { D2 students of } \\
\text { full-time faculty } \\
\text { and student } \\
\text { instructors at the } \\
\text { end of the course, } \\
\text { consisting of an } \\
\text { instructor quality } \\
\text { score, a survey of } \\
\text { student instructors } \\
\text { about their } \\
\text { experience and a } \\
\text { course debriefing } \\
\text { with selected D2 } \\
\text { students. }\end{array}$ & $\begin{array}{l}\text { Analysis of the evaluation } \\
\text { mean scores indicates there } \\
\text { is no evidence to suggest that } \\
\text { the mean instructor-quality } \\
\text { scores of student instructors } \\
\text { are lower than that of } \\
\text { full-time faculty instructors, } \\
\text { and there is weak evidence } \\
\text { to suggest that the mean } \\
\text { instructor-quality scores of } \\
\text { student instructors is actually } \\
\text { higher than that of the } \\
\text { faculty. }\end{array}$ & $\begin{array}{l}\text { Tutors could have } \\
\text { received higher } \\
\text { perceived marks because } \\
\text { they were not involved } \\
\text { with grading students } \\
\text { Study did not have } \\
\text { measured outcomes of } \\
\text { students taught by only } \\
\text { faculty vs students } \\
\text { taught by peer + faculty } \\
\text { combination }\end{array}$ \\
\hline $\begin{array}{l}\text { Nimmo 2008, } \\
\text { USA }\end{array}$ & $\begin{array}{l}\text { Subject: } \\
\text { Prosthodontics } \\
\text { Tutors: D4 } \\
\text { Tutees: D2 }\end{array}$ & $\begin{array}{l}\text { Use of senior dental } \\
\text { students as instructors } \\
\text { in preclinical } \\
\text { prosthodontics } \\
\text { courses for D2 from } \\
\text { the perspective of } \\
\text { preclinical } \\
\text { performance on } \\
\text { graded exercises. }\end{array}$ & $\begin{array}{l}\text { Two groups of } \\
\text { students ( } 34 \text { and } \\
\text { 48) alternated } \\
\text { between faculty } \\
\text { and student } \\
\text { teaching }\end{array}$ & $\begin{array}{l}\text { A statistical } \\
\text { analysis was } \\
\text { performed on the } \\
\text { graded projects for } \\
\text { the two courses, } \\
\text { comparing the } \\
\text { effect of type of } \\
\text { instructor }\end{array}$ & $\begin{array}{l}\text { The results indicate no } \\
\text { significant difference for all } \\
\text { groups. }\end{array}$ & $\begin{array}{l}\text { No monitoring of } \\
\text { instruction or interaction } \\
\text { outside of schooled lab } \\
\text { sessions } \\
\text { Grade inflation may } \\
\text { have obscured some } \\
\text { grading variables } \\
\text { Results may not apply } \\
\text { directly to other } \\
\text { preclinical courses or } \\
\text { disciplines }\end{array}$ \\
\hline $\begin{array}{l}\text { Haj-Ali, 2007, } \\
\text { USA }\end{array}$ & $\begin{array}{l}\text { Subject: } \\
\text { morphology/ } \\
\text { Occlusion } \\
\text { Tutors: D4 } \\
\text { Tutees: D1 }\end{array}$ & $\begin{array}{l}\text { Whether senior dental } \\
\text { students could serve } \\
\text { as effective } \\
\text { instructors in a } \\
\text { two-semester } \\
\text { preclinical laboratory } \\
\text { course and whether } \\
\text { such teaching } \\
\text { experience could } \\
\text { enhance their interest } \\
\text { in academics as a } \\
\text { future career. }\end{array}$ & $\begin{array}{l}\text { D1 students were } \\
\text { randomly } \\
\text { assigned so that } \\
\text { each student was } \\
\text { instructed by a } \\
\text { faculty member } \\
\text { in one semester } \\
\text { and a D4 in the } \\
\text { other semester. } \\
\text { (95) }\end{array}$ & $\begin{array}{l}\text { Course evaluation } \\
\text { forms completed by } \\
\text { the first-year dental } \\
\text { students at the end } \\
\text { of each semester; a } \\
\text { comparison of } \\
\text { students' } \\
\text { performances in } \\
\text { each course } \\
\text { determined by } \\
\text { faculty instructors } \\
\text { and D4s; and the } \\
\text { D4s' self-report of } \\
\text { their teaching } \\
\text { experiences. }\end{array}$ & $\begin{array}{l}\text { Results showed no } \\
\text { significant difference } \\
\text { between the performance of } \\
\text { D4s and faculty instructors } \\
\text { in all criteria evaluated. } \\
\text { Furthermore, there was no } \\
\text { significant difference } \\
\text { between the performance of } \\
\text { students instructed by faculty } \\
\text { members and those } \\
\text { instructed by D4s in either } \\
\text { semester. Despite the fact } \\
\text { that such experience seemed } \\
\text { to have minimal influence on } \\
\text { students' decision to } \\
\text { consider academics as a } \\
\text { future career, D4s do seem to } \\
\text { provide effective instruction } \\
\text { and thereby can serve to } \\
\text { compensate for faculty } \\
\text { shortages. }\end{array}$ & $\begin{array}{l}\text { Some non-response bias } \\
\text { due to lack of full } \\
\text { student participation in } \\
\text { survey } \\
\text { Results may not apply } \\
\text { directly to other } \\
\text { preclinical courses or } \\
\text { disciplines } \\
\text { D4 tutors highly } \\
\text { selected and instructed } \\
\text { by faculty }\end{array}$ \\
\hline
\end{tabular}

\section{Discussion}

Peer tutoring has the theoretical potential to benefit all three parties involved: the tutee, the tutor, and the healthcare educational institution. The tutee learns the material while finding guidance through emotional support and mentorship from upper classmen. The tutors learn the material more in depth while learning how to teach, and also developing interest in academic careers. The institution dealing with greater financial demands can utilize budget-friendly programs while simultaneously developing academic careers. These positive outcomes are entirely dependent on the effectiveness of the tutoring programs to educate tutees at an equal if not higher level than when instructed by faculty. The purpose of this research is to determine in what context previous studies have found success in their CYPT programs, and to elucidate what further studies the dental field still requires in order to make informed decisions on utilization of CYPT programs.

Of the reviewed studies, fifteen examined peer tutoring in medical schools, four in dental schools, and 1 physical therapy program. With 141 medical school programs in the United States and 65 dental school programs, it is 
understandable that there would be more studies from medical schools. (ADA, 2014; AAMC, 2014). Additionally, many dental schools implement informal tutoring programs that have not been the subject of a formal study; therefore, the literature available most likely does not reflect the wide variety of peer tutoring programs in place. However, of the available studies, several were limited in the fact that they involved single institutions and small sample sizes. Only five of the twenty studies involved greater than 100 subjects, while the rest of the studies examined study groups involving less than 100 subjects. (Lake, 1999; Mattges, Marxen, Link et al., 2002; Schaffer, Wile, \& Griggs, 1990; Lopez, Johnson, \& Black, 2010; Perkins, Hulme, \& Bion, 2002). Additionally, seven of the CYPT programs taught a very specific skill set (i.e. portion of the physical exam) which causes concern that the success of those programs may not be generalizable to peer tutoring for other topics. (Haist, Wilson, Brigham, Fosson, \& Blue, 1998; Haist, Wilson, Fosson, \& Brigham, 1997; Barnes, Albanese, Schroeder, \& Reiter, 1978; Goodfellow \& Schofield, 2001; Weyrich, Celebi, Schrauth, Möltner, Lammerding-Köppel, \& Nikendei, 2009; Perkins, Hulme, \& Bion, 2002; Tolsgaard, Gustafsson, Rasmussen, Høiby, Müller, \& Ringsted, 2007).

In order for dental education institutions to make evidence-based decisions on implementation of CYPT programs, the field requires more high powered studies involving CYPT programs that focus on multiple topics and skills. Additionally, dental institutions have the unique opportunity to utilize CYPT programs in preclinical education. Medical education studies on CYPT programs for physical exam and history taking skills are not fully reflective of the skills that one learns in preclinical courses. The physical exam and patient interview focuses on information gathering for diagnostic purposes, whereas preclinical education in dentistry is focused on learning procedural skills for healthcare delivery to patients. Therefore, the dental field is in need of high-powered studies on CYPT programs centered on preclinical education.

In terms of positive benefits for tutors, only five out of the twenty studies assessed tutor outcomes in terms of sentiments about the program. (Haist, Wilson, Brigham, Fosson, \& Blue, 1998; Haist, Wilson, Fosson, \& Brigham, 1997; Barnes, Albanese, Schroeder, \& Reiter, 1978; Buckley \& Zamora, 2007; Haj-Ali, Walker, Petrie, \& Steven, 2007). Although four of the studies found that the tutors enjoyed the experience, (Haist, Wilson, Brigham, Fosson, \& Blue, 1998; Haist, Wilson, Fosson, \& Brigham, 1997; Barnes, Albanese, Schroeder, \& Reiter, 1978; Buckley \& Zamora, 2007) only two studies assessed the likelihood that these tutors would pursue teaching in their careers as a result of their experience (Buckley \& Zamora 2007; Haj-Ali, Walker, Petrie, \& Steven 2007). This aspect of CYPT is vital information for dental education institutions because of the high demand for dental faculty. Additional dental school openings in the U.S. have increased the demand for faculty in recent years. Yet even before these schools opened, a 2007-2008 association report indicated 369 full- and part-time vacant faculty positions. (Okwuje, Sisson, Anderson, \& Valachovic, 2009) Unfortunately, there are also consistent findings that graduating dental classes produce less than $1 \%$ of new dentists with immediate plans to enter teaching. (Okwuje, Anderson, \& Valachovic, 2010)

Thus, it is imperative to the dental field that educational institutions prioritize the development and training of future educators. It has been reported that $69 \%$ of surveyed dental education institutions already utilize formal student teaching programs, in order to stimulate interest in academic careers. (McAndrew, Brunson, \& Kamboj, 2011) CYPT programs have the potential to contribute greatly in the initiative to train and develop future educators, while also greatly benefiting the tutees involved. This makes further research on the qualitative outcomes of CYPT programs for tutors very important to the dental profession as a whole.

The majority of the studies reviewed did not present the tutoring programs in the full context of the associated curriculum. This aspect of the studies is becoming increasingly important as problem-based learning (PBL) curricula and variations of hybrid curricula are adopted over traditional lecture format curricula. Studies have found no statistically significant difference in performance of students taught by experts or non-experts of the subject in PBL tutorials. (Park, Susarla, Cox, Da Silva, \& Howell, 2007) This was attributed to the fact that the role of a tutor in PBL is to facilitate rather than deliver knowledge. These results imply that peer tutors in CYPT programs, despite not having expertise in the subject, might be capable of fulfilling faculty roles in a PBL curriculum. However, further studies on CYPT programs in the context of PBL curricula must be done to determine if this is indeed the case. Additionally, studies on CYPT programs in general need to report more in-depth descriptions of the surrounding curriculum in order for their results to be applicable in curriculum builders' decisions on utilization of CYPT programs for their specific institution. 


\section{Conclusion}

The dental field is in great need of studies on CYPT programs in dental education that cover preclinical education, since this is unique to dental education. Additionally, the focus of future studies should be placed on qualitative outcomes for tutors and their interests in teaching careers. Finally, studies on CYPT programs in general need to thoroughly present the context of their curricula such that if there are beneficial results, the ideologies can be more applicable to other educational institutions.

\section{References}

AAMC [Internet] Washington DC: Association of American Medical Colleges; c1995-2014. Medical schools [cited January 11, 2014]. Retrieved from http://www.aamc.org/about/ medicalschools/

ADA: Professional Resources [Internet]. Chicago: American Dental Association; c1995-2014. Frequently asked questions [cited 2014 Jan 11]. Retrieved from www.ada.org/1444.aspx

Barnes HV., Albanese M., Schroeder J., \& Reiter S. (1978). Senior medical students teaching the basic skills of history and physical examination. Journal of Medical Education, 53(5), 432-434.

Buckley S., \& Zamora J. (2007). Effects of participation in a cross year peer tutoring programme in clinical examination skills on volunteer tutors' skills and attitudes towards teachers and teaching. BMC Medical Education, 7, 20. http://dx.doi.org/10.1186/1472-6920-7-20

Ebbert MR., Morgan PM., \& Harris IB. (1999). A comprehensive student peer-teaching program. Academic Medicine, 74(5), 583-584. http://dx.doi.org/10.1097/00001888-199905000-00051

Glynn LG., MacFarlane A., Kelly M., Cantillon P., \& Murphy AW. (2006). Helping each other to learn--a process evaluation of peer assisted learning. BMC Medical Education, 6, 18. http://dx.doi.org/10.1186/1472-6920-6-18

Goodfellow PB., \& Schofield E. (2001). Peer tutorials amongst medical students. Medical Education, 35(10), 1001-1002. http://dx.doi.org/10.1111/j.1365-2923.2001.1048d.x

Haist SA., Wilson JF., Brigham NL., Fosson SE., \& Blue AV. (1998). Comparing fourth-year medical students with faculty in the teaching of physical examination skills to first-year students. Academic Medicine, 73(2), 198-200. http://dx.doi.org/10.1097/00001888-199802000-00020

Haist SA., Wilson JF., Fosson SE., \& Brigham NL. (1997). Are fourth-year medical students effective teachers of the physical examination to first-year medical students? Journal of General Internal Medicine, 12(3), 177-181. http://dx.doi.org/10.1007/s11606-006-5026-4

Haj-Ali R., Walker MP., Petrie CS., \& Steven J. (2007). Educational necessities to compensate for faculty shortage. Journal of Dental Education, 71(4), 511-515.

Lake DA. (1999). Peer tutoring improves student performance in an advanced physiology course. American Journal of Physiology, 276(6) suppl(2), 86-92.

Lopez N., Johnson S., \& Black N. (2010). Does peer mentoring work? Dental students assess its benefits as an adaptive coping strategy. Journal of Dental Education, 74(11), 1197-1205.

Matthes J., Marxen B., \& Linke RM., et al. (2002). The influence of tutor qualification on the process and outcome of learning in a problem-based course of basic medical pharmacology. Naunyn Schmiedebergs Archives of Pharmacology, 366(1), 58-63. http://dx.doi.org/10.1007/s00210-002-0551-0

McAndrew M., Brunson WD., \& Kamboj K. (2011). A survey of U.S. dental school programs that help students consider academic careers. Journal of Dental Education, 75(11), 1458-1464.

Nestel D., \& Kidd J. (2003). Peer tutoring in patient-centred interviewing skills: experience of a project for first-year students. Medical Teacher, 25(4), 398-403. http://dx.doi.org/10.1080/0142159031000136752

Nimmo A., Mitchell GS., Echeto L., \& Ojha AK. (2008). Effect of dental students as instructors on preclinical performance in prosthodontics. Journal of Dental Education, 72(12), 1488-1492.

Nimmo A., Mitchell GS., Penfield RD., \& Hall A. (2007). Evaluation of dental students as instructors in preclinical prosthodontics and occlusion courses. Journal of Prosthodontics, 16(5), 400-405. http://dx.doi.org/10.1111/j.1532-849X.2007.00226.x

Okwuje I., Anderson E., \& Valachovic RW. (2010). Annual ADEA survey of dental school seniors: 2009 Graduating 
Class. Journal of Dental Education, 74(9), 1024-1045.

Okwuje I., Sisson A., Anderson E., \& Valachovic RW. (2009). Dental school vacant budgeted faculty positions, 2007-08. Journal of Dental Education, 73(12), 1415-1422.

Park SE., Susarla SM., Cox CK., Da Silva J., \& Howell, TH. (2007). Do tutor expertise and experience influence student performance in a problem-based curriculum? Journal of Dental Education, 71(6), 819-824.

Perkins GD., Hulme J., \& Bion JF. (2002). Peer-led resuscitation training for healthcare students: a randomised controlled study. Intensive Care Medicine, 28(6), 698-700. http://dx.doi.org/10.1007/s00134-002-1291-9

Rund DA., Jocoby K., Dahl MK., \& Holman HR. (1977). Clinical learning without prerequisites: students as clinical teachers. Journal of Medical Education, 52(6), 520-522.

Schaffer JL., Wile MZ., \& Griggs RC. (1990). Students teaching students: a medical school peer tutorial programme. Medical Education, 24(4), 336-343. http://dx.doi.org/10.1111/j.1365-2923.1990.tb02449.x

Tolsgaard MG., Gustafsson A., Rasmussen MB., Høiby P., Müller CG., \& Ringsted C. (2007). Student teachers can be as good as associate professors in teaching clinical skills. Medical Teacher, 29(6), 553-557. http://dx.doi.org/10.1080/01421590701682550

Topping KJ. (1996). The effectiveness of peer tutoring in further and higher education: a typology and review of literature. Higher Education, 32, 321-345. http://dx.doi.org/10.1007/BF00138870

Trevino FM., \& Eiland DC Jr. (1980). Evaluation of a basic science, peer tutorial program for first- and second-year medical students. Journal of Medical Education, 55(11), 952-953.

Weyrich P., Celebi N., Schrauth M., Möltner A., Lammerding-Köppel M., \& Nikendei C. (2009). Peer-assisted versus faculty staff-led skills laboratory training: a randomised controlled trial. Medical Education, 43(2), 113-120. http://dx.doi.org/10.1111/j.1365-2923.2008.03252.x 